Relations industrielles

Industrial Relations

\title{
Amendement à notre législation ouvrière
}

\section{Jean-Pierre Després}

Volume 1, numéro 8, avril 1946

URI : https://id.erudit.org/iderudit/1023947ar

DOI : https://doi.org/10.7202/1023947ar

Aller au sommaire du numéro

Éditeur(s)

Département des relations industrielles de l'Université Laval

ISSN

0034-379X (imprimé)

1703-8138 (numérique)

Découvrir la revue

Citer cet article

Després, J.-P. (1946). Amendement à notre législation ouvrière. Relations

industrielles / Industrial Relations, 1(8), 4-8. https://doi.org/10.7202/1023947ar

Tous droits réservés @ C Département des relations industrielles de l’Université Laval, 1946
Ce document est protégé par la loi sur le droit d'auteur. L'utilisation des services d'Érudit (y compris la reproduction) est assujettie à sa politique d'utilisation que vous pouvez consulter en ligne.

https://apropos.erudit.org/fr/usagers/politique-dutilisation/ 


\section{AMENDEMENTS A NOTRE LÉGISLATION OUVRIÈRE}

Le 28 mars, le Lieutenant-Gouverneur a sanctionné cinq lois ouvrières qui avaient été adoptées par la Législature de la Province de Québec. Il s'agit des bills suivants : a) Loi modifiant la Loi des syndicats professionnels (bill $n^{\circ} 22$ ) ; b) Loi modifiant la Loi des relations ouvrières (bill $\mathrm{n}^{\circ} 25 ; c$ ) Loi modifiant la Loi de la convention collective (bill $\left.n^{\circ} 26\right)$; $d$ ) Loi modifiant la Loi du salaire minimum (bill $\mathrm{n}^{\circ} 27$ ) ; e) Loi modifiant la Loi concernant les mécaniciens en tuyauterie (bill $n^{\circ} 32$ ). Les amendements apportés à ces lois ouvrières sont très importants, même s'ils n'affectent pas l'orientation générale de notre législation. En effet, ces amendements, présentés par l'honorable Antonio Barrette, simplifieront énormément l'application des lois mentionnées, et cela, pour le plus grand bénéfice des associations ouvrières et des employeurs. A titre documentaịre nous résumons ici ces amendements en y ajoutant quelques notes explicatives.

\section{a) Loi des syndicats professionnels}

Un amendement apporté à l'article 2 de la Loi des syndicats professionnels décrète que la publication dans la Gazette officielle de Québec de l'avis autorisant la formation d'une association ou syndicat professionnel, constitue en corporation ledit syndicat professionnel. Auparavant, l'avis devait être déposé également au greffe de la Cour supérieure. C'est une simplification de la procédure qui sera appréciée par tous les syndicats qui ont réclamé cette modification à plusieurs reprises.

L'article 17 de la loi permettait à un syndicat de réclamer d'un membre qui cessait d'y adhérer la cotisation d'une période maximum d'un an. L'article a été modifié en réduisant cette période à trois mois.

L'article 19 de la Loi des syndicats professionnels permet aux corporations municipales d'accorder une exemption de taxes sur les immeubles utilisés par un syndicat comme salles de réunions ouvrières. Cet article a été modifié en remplaçant le mot "ouvrières" par le mot "syndicales".

Enfin, le bill $n^{\circ} 22$ donne un effet rétroactif aux dispositions de l'article 1. En d'autres termes, les syndicats déjà formés qui n'ont pas déposé, au moment de leur formation, l'avis d'autorisation au greffe de la Cour supérieure, ne sont pas liés par l'ancienne procédure.

\section{b) Loi des relations ouvrières}

Un nouveau paragraphe est ajouté à l'article 7 de la Loi des relations ouvrières. Pour apprécier le caractère représentatif d'une association, la Commission peut, par règlement soumis aux formalités de l'article 38 , déterminer les conditions auxquelles une personne peut être reconnue comme membre d'une association. A l'Assemblée Législative, l'honorable Antonio Barrette a déclaré que les associations patronales et ouvrières avaient déjà été consultées sur la nécessité d'élaborer des règlements de pratique afin d'assurer une application plus efficace de la loi en réduisant au minimum les possibilités de conflits juridictionnels entre les associations ouvrières. Le Ministère du Travail ne s'immiscera d'aucune façon dans la régie interne des associations ouvrières. Les règlements que déterminera la Commission de relations ouvrières faciliteront au contraire la tâche des associations ouvrières en fixant des critères de reconnaissance pour tous les groupements professionnels.

Une nouvelle rédaction de l'article 19 oblige toute association reconnue et qui a conclu une convention collective, à transmettre deux exemplaires ou deux copies certifiées de ce!le-ci à la Commission. Cette convention col'ective ne prend effet qu'à compter de ce dépôt. Les conditions de travail stipulées dans la convention lient l'employeur et l'association ouvrière de toute façon, mais le dépôt s'impose pour l'association si ce'le-ci désire protéger ses droits à l'égard d'une autre association ouvrière qui chercherait à être certifiéepour fin de reconnaissance. Un alinéa supplér entaire à l'article 19 rend applicable à une convention collective conclue sous la Loi des syndicats professionnels les dispositions de la Loi des relations ouvrières à compter du dépôt de cette convention au bureau du ministre du Travail, et prévoit la transmission de deux copies de cette convention, par le ministre, à la Commission de relations ouvrières.

Quelques autres amendements portent à cinq le nombre des membres de la Commission et précisent sa régie interne.

\section{c) Loi de la convention collective}

Un amendement à l'article 10 stipule que des conóés payés peuvent être rendus obligatoires par décret. Un second amendement en conformité de la Loi de l'aide à l'apprentissage permet aux comités paritaires d'accorder des subventions aux commissions d'apprentissage.

\section{d) Loi du salaire minimum}

L'article 2 de la Loi du salaire minimum est modifié de façon à ne plus exempter de l'application des décrets adoptés sous l'empire de cette loi, les salarićs régis par une convention collective de travail conclue sous la Loi des syndicats professionnels. L'exemption ne subsiste que pour les salariés régis par un décret en vertu de la Loi de la convention collective.

Un nouvel alinéa ajouté à l'article 14 autorise la Commission du salaire minimum à établir le taux du salaire qui doit être payé, pour surtemps, à un enployé engagé et payé à l'heure et non régi par une convention collective de travail, et aussi à déterminer les congćs payés qui devront être accord s aux sa'ariés par leurs employeurs.

Deux alinéas ont été ajoutés à l'article 30 . Le premier décrète que la prescription de l'action civile naissant de la Loi du salaire minimum ou d'une ordonnance rendue sous son empire ne commencera à courir que du premier mai suivant la date du travail, lorsqu'il s'agit de salariés occupés dans des exploitations forestières. Le second alinéa stipule que la mise à la poste d'une lettre recommandée de la Commission à un employeur, réclamant de celui-ci du salaire pour un emploi, interrompt la prescription de l'action laquelle recommence à courir pour une autre période de six mois à compter de la mise à la poste de cette lettre.

(Suite à la page 8) 


\section{INDUSTRIAL SAFETY (")}

\section{True PRevention}

In the first chapter of Industrial Safety (2), edited by Roland P. Blake, a book which overnight and rightly so, became the best industrial safety handbook, the reader will see the fundamental reasons and a synthesis of industrial accident prevention :

1. Accidents are caused, they don't simply happen.

2. It is important to discover the cause (or causes) of each accident, then to eliminate those causes so that similar accidents will not recur.

3. It is even more important to discover and eliminate accidents hazards before they become accident causes.

This is an assumption which, expressed in various languages and applied to different degrees, is incorporated in every safety legislation. On account of our particular interest in the Quebec legislation in this field, it is in order to quote section 4 of the Industrial and Commercial Establishments Act (3) in which appears the intent of the legislator and his desire to deal with the prevention of accidents and professional diseases :

" The industrial and commercial establishments " mentioned in section $3{ }^{(4)}$ (of the Act) shall be built " and kept in such a manner as to secure the safety " of all employed in them; and, in those which " contain mechanical apparatus, the machinery, (" mechanism, gearing, tools and engines shall be so " placed and kept as to afford every security for the " employees. They shall also be kept in the cleanest " possible manner; be sufficiently lighted and have " a sufficient quantity of air for the number of persons " employed; be provided with effective means of " expelling the dust produced during the work, and " also the gases and vapors which escape and the " refuse resulting therefrom; in a word, fulfil all " sanitary conditions necessary for the health of the " persons employed, as required by the regulations " made in virtue of the Quebec Public Health Act ".

Consequently, our legislation takes into account the following conditions which may cause accidents in general and industrial accidents in particular. However, it is in order to see if the law as it reads, even if completed by regulations adopted under its authority, is specific enough to point to various accidents hazards and to cause their elimination.

1. The building itself: The reader will picture immediately the whole series of accidents possibly eaused by a faulty or weak construction. The law is generally broad but, on this point, is clarified by section 2 of the

(1) Second of a number of articles by J. O'Connell-Maher. The first article was published in the March 1946 issue of the Bulletin of Industrial Relations ;

(2) Prentice-Hall, Inc., New York, 1943 ;

(3) Revised Statutes of Quebec, 1941, chapter 175 and amendments ;

(4) i.e manufactories, works, workshops, workyards and mills of every kind and their dependencies as well as commercial establishments, except : $a$. mines governed by the Quebec Mining Act ; $b$. domestic workshops in which no strange workman is employed unless such workshops be classified as dangerous, unwholesome or inccmmodious or unless work be done therein by means of steam boilers, or other motors. regulations dealing with the very construction of buildings to be used as industrial establishments:

" In the eręction of buildings, as well as in alterations " or modifications to the same, care must be taken " to avoid, at the very outset, all defects in connection " with their laying out, their safety and their salubrity, " which it would be difficult to remedy later on. For " that purpose, the architects' plans should be first (" submitted to the inspector ).

There is consequently a possible control by the Industrial and Commercial Establishments Inspection Service of the solidity and the layout of the building previous to its construction; however, such verification is subject to hereinafter mentioned and analysed minimum standards inasmuch as the following points are concerned :

Passages: The law provides that the main passages must be at least 48 inches wide, and the side passages, 24 inches. Is this sufficient, even if we are dealing with an absolute minimum? The reader may draw his own conclusions especially if he is already aware that under the Quebec Public Buildings Safety Act, the width of alleys, passages and corridors, aside from being of a minimum of 30 inches, must further be calculated in proportion to the number of seats, eighteen inches being allowed for every hundred occupants.

Passages, in conformity with the regulations, must be kept free. This provision is an essential one and is intended to prevent jams and falls.

Exits and doors: Main doors must be at least 48 inches wide and 7 feet high; they must always open outwards. Doors used as exits to passages must be at least as wide as such passages ; should they be intended as emergency exits, they must swing towards the exits.

It is to be noted that main doors do not, under the law, have necessarily to be equipped with locks automatically opening by pressure from within the buildings, as provided for in public buildings. Should an industrial establishment owner be satisfied with the strict enforcement of the law, would not life of persons be endangered in case of fire or panic?

Staircases: The regulations under the Industrial and Commercial Establishments Act state that main staircases must be at least 4 feet wide and that there must not be more than 12 feet between landings; that there must be a sufficient number of such staircases to allow of the building being immediately and easily cleared. So as to prevent falls, the regulations provide for the staircases to be kept free and for the installation of railings.

However, there is no set standard for the minimum or maximum height of the steps or the minimum or maximum depth of such steps. Could we see here a possible source of accidents? The Quebec Public Buildings Safety Act and the Regulations rendered under its authority provide for a maximum depth of 11 inches and a maximum height of 8 inches for steps. Why not impose similar conditions in industrial establishments? There is no further reference, in the legislation dealing with industrial establishments, to the

(Continued on page 8) 


\section{AMENDMENTS TO OUR LABOUR LEGISLATION}

On the 28th of March the Lieutenant-Governor sanctioned five labour laws which had been previously passed by the Leglisative Assembly of the Province of Quebec. The bills in question are entitled as follows : $a$ ) An Act to amend the Professional Syndicates' Act (bill No. $22) ; b$ ) An Act to amend the Labour Relations Act (bill No. 25) ; c) An Act to amend the Collective Agreement Act (bill No. 26); d) An Act to amend the Minimum Wage Act (bill No. 27) ; e) An Act to amend the Pipe-Mechanics Act (bill No. 32). The amendments to these labour laws are quite important even though they do not affect the general trend of ourlegislation. Indeed, these amendnents, presented by the Honourable Antonio Barrette, will greatly simplify the carrying out of these Acts and prove highly useful to employees' and employers' associations. A summary of these amendr ents with explanatory notes will be found hereinbelow.

\section{a) Professional Syndicates' Act}

An amendment to section 2 of the Professional Syndicates' Act enacts that the publication, in the Quebec Official Gazette, of the notice authorizing the formation of an association or professional syndicate incorporates the said professional syndicate. Formerly, it was also necessary to deposit this notice in the office of the Superior Court. This simplification of procedure will be appreciated by all the syndicates that have repeatedly requested it.

Section 17 of the Act entitled a syndicate to claim from a member ceasing to adhere thereto an assessment for a maximum period of one year. This section has been amended by reducing this period to three months.

Section 19 of the Professional Syndicates' Act allows municipal corporations to grant an exemption of taxes on immoveables utilized by a syndicate as hall for workmen's meetings. This section has been amended by replacing the word : " workmen's ) by the word : " syndicate $)$.

Finally, bill No. 22 gives a retroactive effect to the provisions of section 1 . In other words, if the syndicates already formed did not deposit the notice of authorization in the office of the Superior Court at the time of their formation, the former procedure no longer binds them to do so.

\section{b) Labour Re!ations Act}

A new paragraph is added to section 7 of the Labour Relations Act. In order to assure itself of the representative character of an association, the Board may, by bylaw subject to the formalities of section 38, determine the conditions on which a person $\mathrm{m}$ ay be recognized as a menber of an association. In the Legislative Assembly, the Honourable Antonio Barrette declared that the enployers' and employees' associations had already been consu'ted about the necessity of drawing up practical by-laws that would ensure a more efficient enforcement of the Act by reducing to the limit the possibilities of jurisdictional disputes between labour associations. The Department of Labour shall in no way whatever interfere in the internal administration of labour unions. On the contrary, the by-laws which will be determined by the Labour Relations Board will make the labour associations' work easier by establishing criterions for the recognition of all professional groups.

Section 19, as newly worded, obliges every association recognized under the Act, and which has entered into a collective agreement, to transmit two certified copies thereof to the Board. Such collective agreement shall not take effect until such deposit is made. Notwithstanding the foregoing provisions, the conditions of work stipulated in the agreement are binding upon the employer and the labour association, but the said association must make the deposit if it intends to protect its rights with regard to any other labour association that would try to obtain certification for the purpose of being recognized in its place. A supplementary paragraph of section 19 makes the provisions of the Labour Relations Act applicable to a collective agreement entered into under the Professional Syndicates' Act as from the date of the deposit of such agreement in the office of the Minister of Labour and provides for the transmission of two copies of such agreement, by the Minister, to the Labour Relations Board.

Other amendments bring up to five (5) the number of members of the Board and deal with the internal administration of that body.

\section{c) Collective Agreement Act}

An amendment to section 10 stipulates that vacations with pay may be rendered obligatory by decree. A second amendment, in conformity with the Apprenticeship Assistance Act, authorizes any parity committee to grant subsidies to apprenticeship commissions.

\section{d) Minimum Wage Act}

Section 2 of the Minimum Wage Act is amended so that it no longer exempts from the application of the ordinances enacted under the said Act the employees subject to a collective labour agreement passed under the Professional Syndicates' Act. The exception is maintained only for employees subject to a decree passed under the Collective Agreement Act.

A new section inserted after section 14 authorizes the Minimum Wage Commission to determine the rate of wages to be paid, for overtime, to an employee engaged and paid by the hour and not subject to a collective labour agreement, and also to determine the vacations with pay to be granted to employees by their employers.

Two paragraphs have been added to section 30 . The first enacts that the prescription of a civil action arising from the Minimum Wage Act or from an ordinance rendered under this Act shall run only as from the first of May following the date of the work done in the case of employees engaged in forest operations. The second paragraph enacts that the mailing of a registered letter from the Minimum Wage Commission to an employer claiming wages for an employment shall suspend the prescription of the action, which prescrip-

(Continued on page 8 ) 


\section{LA SÉCURITÉ INDUSTRIELLE ${ }^{(1)}$}

\section{La VÉRitable PRÉVENTION}

Le premier chapitre de Industrial Safety ${ }^{(2)}$, édité par Roland P. Blake, volume qui est devenu rapidenient et à juste titre le meilleur manuel de sécurité industrielle, nous indique les raisons fondamentales et la synthèse de la technique de prévention des accidents :

$1^{\circ}$ Il y a une cause à chaque accident : celui-ci n'est jamais entièrement l'œuvre du hasard ;

$2^{\circ}$ Il est nécessaire de déceler la cause (ou les causes) d'un accident et de les éliminer, afin de prévenir d'autres accidents de même nature ;

$3^{\circ} \mathrm{Il}$ est enfin plus désriable de découvrir et de faire disparaitre les causes d'accidents avant que ceux.ci ne se produisent.

Ce sont des postulats que nous retrouvons sous diverses formes et à des degrés différents dans les législations de sécurité. Puisque la réglementation du Québec dans ce domaine nous intéresse particulièrement, relisons l'article 4 de la Loi des établissements industriels et commerciaux ${ }^{(3)}$ qui illustre bien l'intention du législateur et son désir de prévenir les accidents et les maladies professionnelles :

"Les établissements industriels et commerciaux " visés par l'article 3 (4) (de la loi) doivent être cons" truits et tenus de manière à assurer la sécurité du " personnel ; et dans ceux qui contiennent des appa" reils mécaniques, les machines, mécanismes, appa" reils de transmission, outils et engins doivent être " installés et entretenus dans les meilleures conditions " possibles pour la sécurité des travailleurs. Ils " doivent encore être tenus dans les meilleures condi" tions possibles de propreté ; offrir un éclairage et " une circulation d'air suffisants pour le nombre des " employés ; présenter des moyens efficaces d'expul" sion des poussières produites au cours du travail " ainsi que des gaz et des vapeurs qui s'y dégagent " et des déchets qui en résultent; offrir, en un mot, " toutes les conditions de salubrité nécessaires à la " santé du personnel, tel que requis par les règle" ments établis en vertu de la Loi de l'hygiène publique " de Québec. "

Notre législation tient donc compte des conditions ci-après qui sont susceptibles de provoquer des accidents, en particulier, des accidents de travail. Voyons toutefois si le texte législatif même complété par la réglementation adoptée en exécution d'icelui, est assez précis pour viser certains risques d'accident et provoquer leur élimination :

(1) Deuxième article d'une série préparée par M. J. O'ConnellMaher ; le premier article a été publié dans le numéro de mars 1946 du Bulletin des relations industrielles;

(2) Prentice-Hall, Inc., New-York, 1943 ;

(3) Statuts refondus de Québec, 1941, chapitre 175 et amendements ;

(4) C'est-à-dire les manufactures, fabriques, usines, chantiers, ateliers de tous genres et leurs dépendances ainsi que les établissements commerciaux, à l'exception : $a$ ) des mines régies par la Loi des mines de Québec ; $b$ ) des ateliers de famille où aucun étranger n'est employé, à moins que ces ateliers soient classés comme dangereux, insalubres ou incommodes ou que le travail s'y fasse à l'aide de chaudières à vapeur ou autres moteurs. $1^{\circ} L^{\prime}$ immeuble: On réalisera immédiatement toute la série d'accidents qui peuvent être causés par un vice ou une faiblesse de construction. Le texte de la loi est assez général, mais il est expliqué à l'article 2 des règlements qui a trait à la construction des immeubles destinés à servir comme établissements industriels :

" La construction des bâtiments de même que les

" changements et modifications qui peuvent y être

" apportés doivent être faits de façon à écarter à

" l'origine les vices d'aménagement, de sécurité ou de

" salubrité auxquels il serait très difficile de remédier

" plus tard. Dans ce but, les plans d'architecte

( doivent préalablement être soumis à l'inspecteur.)

Il y a done contrôle préalable possible de la part du Service d'inspection des établissements industrie's et commerciaux, en ce qui concerne la solidité et l'aménagement de l'immeuble ; cependant, cette vérification est sujette aux standards minima énumérés et analysés ciaprès quant aux points suivants :

Les passages: La réglementation prévoit que les passages principaux doivent avoir au moins 48 pouces de largeur et les passages secondaires, 24 pouces. Est-ce suffisant, même s'il s'agit d'un minimum absolu? Le lecteur tirera ses propres conclusions, surtout s'il sait déjà qu'en exécution de la Loi des édifices publics du Québec, la largeur des allées, des passages et des couloirs, en plus d'être de 30 pouces au minimum, doit être proportionnée au nombre de places destinées aux occupants, soit de 18 pouces par cent occupants.

Conformément aux règlements, les passages doivent être libres. Cette disposition est essentielle et a pour but de prévenir des encombrements et des chutes.

Les issues et les portes: Les portes principales doivent avoir au moins 48 pouces de largeur et 7 pieds de hauteur ; elles doivent toujours s'ouvrir dans le sens de la sortie. Les portes servant d'issue à des corridors ne doivent pas avoir une largeur moindre que celle de ces corridors et si elles doivent servir d'issue en cas de panique, il faut qu'elles s'ouvrent vers l'extérieur.

Notons qu'il n'est pas nécessaire, d'après la loi, que les portes principales soient munies d'une serrure qui s'ouvre automatiquement par pression de l'intérieur, comme c'est le cas pour les édifices publics. Si, dans ce cas, le propriétaire d'un établissement industriel se contente de se conformer aux standards minima, n'y a-t-il pas un danger pour la vie du personnel en cas d'incendie ou de panique?

Les escaliers: Les règlements en exécution de la Loi des établissements industriels et commerciaux décrètent que les escaliers principaux ne doivent pas avoir moins de 4 pieds de largeur et pas plus de 12 pieds entre chaque palier ; qu'il doit y en avoir un nombre suffisant pour permettre l'évacuation immédiate et facile de l'établissement. En vue de prévenir les chutes, la réglementation exige que ces escaliers soient maintenus en bon état et munis de garde.

Cependant, il n'y a aucune prescription relative à la hauteur minimum ou maximum des marches ou à leur profondeur minimum ou maximum. N'y a-t-il pas là une source d'accidents? On retrouve, dans les règle(Suite à la page 2) 


\section{BIBLIOGRAPHIE}

Cette liste, forcément incomplète, indique, sans approuver pour autant leur contenu, certaines publications récentes où le lecteur pourra se renseigner sur l'évolution des idées et des faits dans le domaine des relations industrielles.

\section{VOLUMES ET TRACTS}

Craft Unions of Ancient and Modern Times - John P. Frex American Federation of Labor.

Industrial Relations - Third Conference of American States Members of the International Labour Organization, Mexico City, 1946.

Sécurité syndicale et convention collective - Gérard DION, ptre Cahiers de la Faculté des Sciences sociales de Laval, vol. VI, $\mathrm{n}^{\circ} 2$.

Changements démographiques et professionnels au CanadaMinistère fédéral du Travail.

New Concepts in Collective Bargaining - American Management Association. Personnel Series No. 97.

\section{Périodiques}

CANADA

En relisant les conférences des patrons - Le Travail, avril 1946, p. 8 .

L'assurance-maladie aux Etats-Unis - Le Monde ouvrier, mars 1946, p. 3.

Une charte des relations industrielles pour l'hémisphère occidental Le Monde ouvrier, mars 1946, p. 5.

Conditions Affecting Workers' Family Life - The Canadian Unionist, mars 1946, p. 54 .

Australia's Arbitration System - John Brie Ars.-Trades and Labor Congress Journal, mars 1946, p. 36.

Un programme de travaux de développement recommandé par une commission du B. I. T. - Trades and Labor Congress Journal, mars 1946, p. 45.

National Employment Committee of the Unemployment Insurance Commission - Trades and Labor Congress Journal, mars 1946, p. 7.

Labor, Management Can Work Together - H. Ross Rutherford. - Labour and Learning, Dalhousie University, Halifax, mars 1946.

Veterans are Still Human - Bulletin of the Maritime Bureau of Industrial Relations, Halifax, mars 1946, p. 2.

Medical Services in the Small Industrial Plant - Bulletin of the Maritime Bureau of Industrial Relations, Halifax, mars 1946, p. 6.

\section{ETATS-UNIS}

Negotiating Maintenance-of-Membership Demands - The Management Review, mars 1946, p. 88.

Setting up a Personnel Budget - The Management Review, mars 1946 , p. 85.

Labor Rises Again - American Federationist, mars 1946, p. 15.

Employment Interviewing - The Management News, mars 1946, p. 3.

A Strike Is Right When It Is Moral - The Labor Leader, 16 février 1946.

Today's Encyclicals - Work-by John. Doebele - The Catholic Worker, New York, mars 1946.

\section{FRANCE}

Autour de la Sécuritế sociale-Syndicalisme, Confédération française des travailleurs catholiques, 23 février 1946.

Le travail à la chaine est-il compatible avec la digni té del'homme ?Syndicalisme, C.F.T.C., 9 mars 1946.

\section{AMENDEMENTS A NOTRE LËGISLATION...}

(Suite de la page 4)

Enfin, la Commission pourra, avec l'autorisation du Ministre du Travail et du Lieutenant-Gouverneur en conseil, acquérir, à même ses fonds, des immeubles et des terrains et y ériger des bâtisses pour les fins de son administration et de ses services.

\section{e) Loi des mécaniciens en tuyauterie}

Deux amendements ont été apportés à cette loi. L'un prévoit des pénalités pour les infractions aux règiements et l'autre fixe le pouvoir de réglementer l'exécution de travaux de plomberie dans les municipalités dont la population excède cinq mille âmes.

Enfin, il faut noter que tous ces amendements avaient d'abord été approuvés par le Conseil supérieur du Travail qui groupe des représentants des principales associations patronales et ouvrières ainsi que des économistes et des sociologues.

Jean-Pierre Després.

\section{AMENDMENTS TO OUR LABOUR...}

(From page 6)

tion shall run again for another period of six months as from the mailing of such letter.

Finally, the Minimum Wage Commission may, out of its funds, with the authorization of the Minister of Labour and of the Lieutenant-Governor in Council, acquire immoveables and lands and erect buildings thereon for the jurpose of occupying them for its administration and services.

e) Pipe-Mechanics Act

There are two amendments to this Act. The first provides penalties for contravention to regulations enacted under the Act and the second adds to section 29, as a supplementary provision, the power to regulate the carrying out of plumbing works in municipalities the population of which exceeds five thousand souls.

Finally, it is to be noted that all these amendments had first been approved by the Superior Labour Council, a body which is composed of the representatives of the leading employers' and employees' associations as well as of economists and sociologists.

\section{Jean-Pierre Després.}

\section{INDUSTRIAL SAFETY}

\section{(From page 5)}

angle of staircases or to the nosing of steps and in a specific way. However, we grieve each year about the high number of costly and even fatal accidents in industry, and occurring in staircase traffic. Is there any sound reason for not raising safety standards?

\section{J. O'Connell-Maher.}

(To be continued) 